\title{
KOMPUTASI GUI-R UNTUK PEMODELAN REGRESI NONPARAMETRIK BIRESPON POLINOMIAL LOKAL PADA PENGARUH SUKU BUNGA BI TERHADAP INDEKS HARGA SAHAM GABUNGAN DAN KURS USD
}

\author{
Rudi Saputro Setyo Purnomo', Suparti ${ }^{2}$, Sudarno ${ }^{3}$ \\ 1, 2, 3 Departemen Statistika FSM Universitas Diponegoro \\ rudipurnomo505@gmail.com
}

\begin{abstract}
ABSTRAK
Economy is one of important indicator of development country. Capital market is one of important tool in economy. The development of the capital market in Indonesian can be seen based on the composite stock price index (CSPI). Other than capital market, international trade is an important tool in the economy. Existence of the international trade generates exchange rate, one of which is USD exchange rate. Exchange rate can be increased and weakened, so it's stability needs to be maintained. One of the factor that can influence CSPI and USD exchange rate is the BI interest rate. To be able to predict the value of CSPI and USD exchange rate then do the birespon regression modelling because between CSPI and USD exchange rate there are relationship. The regression model approach which used in this research is local polynomial. This approach has high adaptability with data. To make the modelling easier so this research arrange Graphycal User Interface (GUI) by using R software. The local polynomial birespon regression is applied to CSPI and USD exchange rate data based on BI interest rate by using GUI. The optimal modal is obtained by General Cross Validation (GCV) optimation. The optimal model is model by combination of sequences two and three, bandwidths 6 and 2,7, and local points 5,75 and 6. The value of $\mathrm{R}$ Square is $66,68 \%$ and the mean absolute percentage error (MAPE) is $4,0798 \%$. This MAPE shows that the optimal model has very high accuration in prediction the data because this value of MAPE less than $10 \%$.
\end{abstract}

Keywords: CSPI, USD exchange rate, BI interest rate, birespon, local polynomial, GUI.

\section{PENDAHULUAN}

Indonesia sebagai sebuah negara berkembang terus berusaha menjaga dan meningkatkan perekonomiannya. Pasar modal (capital market) merupakan salah satu sarana yang efektif dalam mengalokasikan dana masyarakat dan investor asing guna mendorong pertumbuhan ekonomi $^{[9]}$. Sehingga perkembangan pasar modal dapat digunakan untuk melihat perekonomian Indonesia. Indeks Harga Saham Gabungan (IHSG) merupakan salah satu indikator perkembangan pasar modal. Selain pasar modal, perdagangan internasional merupakan kegiatan yang penting bagi perekonomian suatu negara. Adanya perdagangan internasional melatarbelakangi terbentuknya kurs, salah satunya adalah kurs USD. Nilai tukar 
dapat mengalami pelemahan (depresiasi) atau penguatan (apresiasi) sehingga dapat berpengaruh pada perekonomian. Salah satu faktor yang berpengaruh pada IHSG dan kurs USD adalah suku bunga BI. Hal tersebut ditunjukkan dengan hasil penelitian yang dilakukan oleh ${ }^{[5,6]}$. Berdasarkan penelitian yang dilakukan oleh ${ }^{[7]}$ diketahui bahwa terdapat kausalitas antara IHSG dengan nilai tukar. Atas dasar uraian tersebut maka perlu dilakukan pemodelan IHSG dan kurs USD berdasarkan suku bunga BI dengan melibatkan hubungan antara IHSG dan kurs USD.

Pemodelan tersebut dapat dilakukan dengan menggunakan model regresi. Pemodelan regresi nonparametrik merupakan salah satu pemodelan regresi yang digunakan jika pola data tidak membentuk pola tertentu ${ }^{[2]}$. Salah satu metode pemodelan regresi nonparametrik adalah polinomial lokal yang memiliki kelebihan dalam beradaptasi terhadap data ${ }^{[3]}$. Apabila dalam pemodelan regresi terdapat dua variabel respon maka dinamakan regresi birespon. Pemodelan birespon ini mensyaratkan adanya korelasi antar responnya. Penelitian mengenai regresi birespon dilakukan oleh ${ }^{[8]}$ dengan menggunakan metode Spline Truncated yang dapat memodelkan pengaruh Kurs USD dan jumlah uang beredar terhadap IHSG dan inflasi. Penelitian tersebut menghasilkan model dengan akurasi cukup baik dikarenakan nilai Mean Percentage Error (MAPE) yang dihasilkan adalah 43,446\%.

Sampai saat ini komputasi pemodelan regresi nonparametrik khususnya pemodelan regresi birespon polinomial lokal masih terbatas pada alat komputasi tertentu yang berbasis command line interface, sehingga memerlukan pemahaman untuk memberikan perintah dalam bentuk tulisan. Pengembangan alat komputasi untuk melakukan pemodelan tersebut berbasis grafis atau yang dikenal graphycall user interface (GUI) perlu dilakukan dengan tujuan agar dalam penggunaannya lebih mudah dipahami. Berdasarkan uraian tersebut maka dalam penelitian ini akan dilakukan pemodelan regresi nonparametrik birespon polinomial lokal untuk memodelkan pengaruh tingkat suku bunga BI terhadap Indeks Harga Saham Gabungan (IHSG) dan nilai tukar rupiah terhadap USD (Kurs USD). Pemodelan akan dilakukan dengan komputasi Graphical User Interface (GUI) Program R-Studio.

\section{TINJAUAN PUSTAKA}

\subsection{Regresi Nonparametrik}

Misalkan diberikan pasangan variabel random $\mathrm{Y}$ dan $\mathrm{X}$, dengan $\left(x_{i}, y_{i}\right), i=1,2, \ldots, n$ adalah nilai dari $\mathrm{X}$ dan $\mathrm{Y}$. Model regresi untuk $x_{i}$ dan $y_{i}$ dinyatakan dengan:

$$
y_{i}=g\left(x_{i}\right)+\varepsilon_{i}
$$


$\varepsilon_{i}$ merupakan eror acak sedangkan $g$ merupakan fungsi regresi. Pemodelan regresi nonparametrik merupakan salah satu pemodelan regresi untuk data yang tidak membentuk pola tertentu. Karena tidak membentuk pola tertentu maka dalam pemodelan nonparametrik diharapkan data mencocokan sendiri bentuk kurva regresinya ${ }^{[2]}$.

\subsection{Fungsi Kernel}

Dalam pemodelan regresi polinomial lokal digunakan metode estimasi Weighted Least Square sehingga digunakan bobot dalam mengestimasi parameter regresi. Menurut ${ }^{[4]}$ salah satu fungsi yang digunakan tersebut adalah fungsi kernel, yaitu sebuah fungsi riil, kontinu, terbatas, dan simetris, serta memenuhi:

$$
\int_{-\infty}^{\infty} K(u) d u=1
$$

Fungsi kernel dengan faktor skala $h$ memiliki persamaan sebagai berikut:

$$
K_{h}(u)=\frac{1}{h} K\left(\frac{u}{h}\right)
$$

Menurut Hardle dalam ${ }^{[11]}$, terdapat beberapa macam fungsi kernel, yaitu:

\begin{tabular}{|l|l|l|l|}
\hline Nama Fungsi & Fungsi & Nama Fungsi & Fungsi \\
\hline Uniform & $K(x)=\frac{1}{2} I(|x| \leq 1)$ & Triweight & $K(x)=\frac{35}{32}\left(1-x^{2}\right)^{3} I(|x| \leq 1)$ \\
\hline Segitiga & $K(x)=(1-|x|) I(|x| \leq 1)$ & Cosinus & $K(x)=\frac{\pi}{4} \cos \left(\frac{\pi}{2} x\right) I(|x| \leq 1)$ \\
\cline { 1 - 2 } Epanechnikov & $K(x)=\frac{3}{4}\left(1-x^{2}\right) I(|x| \leq 1)$ & Gaussian & $K(x)=\frac{1}{\sqrt{2 \pi}} e^{\left(-\frac{1}{2} x^{2}\right)},-\infty<x<$ \\
\cline { 1 - 2 } Kuadrat & $K(x)=\frac{15}{16}\left(1-x^{2}\right)^{2} I(|x| \leq 1)$ & & $\infty$ \\
\hline
\end{tabular}

\subsection{Regresi Polinomial Lokal}

Pada pemodelan regresi nonparametrik polinomial lokal, fungsi regresi pada Persamaan 1 didekati dengan deret taylor yang memuat polinomial berderajat $m$ sebagai berikut ${ }^{[3]}$ :

$$
g(x)=g\left(x_{o}\right)+g^{\prime}\left(x_{o}\right)\left(x-x_{o}\right)+g^{\prime \prime}\left(x_{o}\right) \frac{\left(x-x_{o}\right)^{2}}{2 !}+g^{\prime \prime \prime}\left(x_{o}\right) \frac{\left(x_{i}-x_{o}\right)^{3}}{3 !}+\cdots+g^{(m)}\left(x_{o}\right) \frac{\left(x-x_{o}\right)^{m}}{m !}
$$

Sehingga diperoleh:

$$
y_{i}=\sum_{j=0}^{m} \frac{g^{(j)}\left(x_{0}\right)}{j !}\left(x_{i}-x_{0}\right)^{j}+\varepsilon_{i} \quad=\sum_{j=0}^{m} \beta_{j}\left(x_{i}-x_{o}\right)^{j}+\varepsilon_{i}, \quad i=1,2, \ldots, n
$$

Dalam bentuk matriks Persamaan 5 dapat dinyatakan dengan $\boldsymbol{Y}=\boldsymbol{X} \boldsymbol{\beta}+\boldsymbol{\varepsilon}$. Vektor $\boldsymbol{\beta}$ dapat diestimasi menggunakan WLS dengan meminimumkan:

$$
L=(\boldsymbol{Y}-\boldsymbol{X} \boldsymbol{\beta})^{\prime} \boldsymbol{K}(\boldsymbol{Y}-\boldsymbol{X} \boldsymbol{\beta})
$$

dengan $\boldsymbol{K}=\operatorname{diag}\left\{K_{h}\left(x_{i}-x_{0}\right)\right\} ; i=1,2, \ldots, n$ dan:

$\boldsymbol{X}=\left[\begin{array}{ccccc}1 & \left(x_{1}-x_{0}\right) & \left(x_{1}-x_{0}\right)^{2} & \cdots & \left(x_{1}-x_{0}\right)^{m} \\ 1 & \left(x_{2}-x_{0}\right) & \left(x_{2}-x_{0}\right)^{2} & \cdots & \left(x_{2}-x_{0}\right)^{m} \\ \vdots & \vdots & \vdots & \ddots & \vdots \\ 1 & \left(x_{n}-x_{0}\right) & \left(x_{n}-x_{0}\right)^{2} & \cdots & \left(x_{n}-x_{0}\right)^{m}\end{array}\right]_{n \times(m+1)} \quad \boldsymbol{Y}=\left[\begin{array}{c}y_{1} \\ y_{2} \\ \vdots \\ y_{n}\end{array}\right]_{n \times 1} \quad \boldsymbol{\beta}=\left[\begin{array}{c}\beta_{0} \\ \beta_{1} \\ \beta_{2} \\ \vdots \\ \beta_{m}\end{array}\right]_{(m+1) \times 1}$ 
Dalam regresi polinomial lokal, pemilihan bandwidth $h$ merupakan suatu hal yang sangat penting. Selain bandwidth, titik lokal $x_{0}$ dan order juga merupakan hal yang penting ${ }^{[1]}$. Sehingga untuk mendapatkan model yang optimal maka dicobakan kombinasi-kombinasi bandwidth, order, serta titik lokal.

\subsection{Model Regresi Birespon}

Tujuan dari pemodelan ini adalah untuk mengetahui pengaruh variabel prediktor terhadap respon dengan mempertimbangkan hubungan antar respon. Misalkan dimiliki pasangan observasi $\left(y_{1 i}, y_{2 i}, x_{i}\right), i=1,2, \ldots, n$, model regresi birespon untuk $\left(y_{1 i}, y_{2 i}, x_{i}\right)$ adalah:

$$
y_{k i}=g_{k}\left(x_{i}\right)+\varepsilon_{k i}, \quad k=1,2
$$

dengan $g_{k}$ adalah fungsi regresi dari respon ke- $k$ dan $\varepsilon_{k i}$ eror acak dengan $E\left(\varepsilon_{k i}\right)=0$ dan $\operatorname{Var}\left(\varepsilon_{k i}\right)=\sigma_{k}$. Selanjutnya untuk semua $k=1,2$ dan $i 1,2, \ldots, n$ Persamaan 7 dapat disederhanakan menjadi:

$$
\boldsymbol{Y}^{*}=\boldsymbol{g}^{*}+\boldsymbol{\varepsilon}^{*}
$$

dengan:

$$
\boldsymbol{Y}^{*}=\left[\begin{array}{l}
\boldsymbol{Y}_{1} \\
\boldsymbol{Y}_{2}
\end{array}\right]_{2 n \times \mathbf{1}} \quad \boldsymbol{g}^{*}=\left[\begin{array}{l}
\boldsymbol{g}_{1} \\
\boldsymbol{g}_{2}
\end{array}\right]_{2 n \times 1} \quad \boldsymbol{\varepsilon}^{*}=\left[\begin{array}{c}
\boldsymbol{\varepsilon}_{\mathbf{1}} \\
\boldsymbol{\varepsilon}_{2}
\end{array}\right]_{2 n \times 1} \quad \boldsymbol{Y}_{k}=\left[\begin{array}{c}
y_{k 1} \\
y_{k 2} \\
\vdots \\
y_{k n}
\end{array}\right]_{n \times 1} \quad g_{k}=\left[\begin{array}{c}
g_{k}\left(x_{1}\right) \\
g_{k}\left(x_{2}\right) \\
\vdots \\
g_{k}\left(x_{n}\right)
\end{array}\right]_{n \times 1} \quad \varepsilon_{k}=\left[\begin{array}{c}
\varepsilon_{k 1} \\
\varepsilon_{k 2} \\
\vdots \\
\varepsilon_{k n}
\end{array}\right]_{n \times 1}
$$

$\boldsymbol{g}^{*}$ diperoleh menggunakan metode estimasi WLS dengan meminimumkan Persamaan 9.

$$
\boldsymbol{L}=\left(\boldsymbol{Y}^{*}-\boldsymbol{g}^{*}\right)^{\prime} \boldsymbol{V}^{-1}\left(\boldsymbol{Y}^{*}-\boldsymbol{g}^{*}\right)
$$

${ }^{[14]} \boldsymbol{V}$ adalah matriks varian kovarian $\boldsymbol{Y}_{1}$ dan $\boldsymbol{Y}_{2}$ yang berukuran $2 n \times 2 n$, sebagai berikut:

$$
\boldsymbol{V}=\left[\begin{array}{ll}
\boldsymbol{\Sigma}_{11} & \boldsymbol{\Sigma}_{12} \\
\boldsymbol{\Sigma}_{12} & \boldsymbol{\Sigma}_{22}
\end{array}\right]
$$

dengan $\boldsymbol{\Sigma}_{a b}=\left[\begin{array}{cccc}\sigma_{a b} & 0 & 0 & 0 \\ 0 & \sigma_{a b} & 0 & 0 \\ \vdots & \vdots & \ddots & \vdots \\ 0 & 0 & 0 & \sigma_{a b}\end{array}\right]_{n \times n}, a=b=1,2$ dan $\sigma_{a b}$ adalah kovarian respon a dengan $\mathrm{b}$.

\subsection{Regresi Nonparametrik Birespon dengan Estimator Polinomial Lokal}

Pada pemodelan regresi birespon polinomial lokal dengan order respon ke- $k m_{k}$ dan titik lokal respon ke- $k x_{o}{ }^{(k)}$, fungsi regresi birespon pada Persamaan 8 dapat didekati dengan Persamaan 4, sehingga diperoleh:

$$
\begin{aligned}
y_{k i} & =g_{k}\left(x_{o}{ }^{(k)}\right)+g_{k}{ }^{\prime}\left(x_{o}{ }^{(k)}\right)\left(x_{i}-x_{o}{ }^{(k)}\right)+g_{k}{ }^{\prime \prime}\left(x_{o}{ }^{(k)}\right) \frac{\left(x_{i}-x_{o}{ }^{(k)}\right)^{2}}{2 !}+\cdots+g_{k}{ }^{\left(m_{k}\right)}\left(x_{o}{ }^{(k)}\right) \frac{\left(x_{i}-x_{o}{ }^{(k)}\right)^{m_{k}}}{m_{k} !}+\varepsilon_{k i} \\
& =\sum_{j=0}^{m_{k}} \frac{g_{k}{ }^{(j)}\left(x_{o}{ }^{(k)}\right)}{j !}\left(x_{i}-x_{o}{ }^{(k)}\right)^{j}+\varepsilon_{k i}=\sum_{j=0}^{m_{k}} \beta_{j_{k}}\left(x_{i}-x_{o}{ }^{(k)}\right)^{j}+\varepsilon_{k i}, \quad i=1,2, \ldots, n ; k=1,2
\end{aligned}
$$

Untuk semua pengamatan $i=1,2, \ldots, n$, selanjutnya dapat disederhanakan menjadi:

$$
\boldsymbol{Y}^{*}=\boldsymbol{X}^{*} \boldsymbol{\beta}^{*}+\boldsymbol{\varepsilon}^{*}
$$

dengan: 


$$
\begin{aligned}
& \boldsymbol{Y}^{*}=\left[\begin{array}{l}
\boldsymbol{Y}_{1} \\
\boldsymbol{Y}_{2}
\end{array}\right]_{2 n \times 2 n} \quad \boldsymbol{X}^{*}=\left[\begin{array}{cc}
\boldsymbol{X}_{1} & \mathbf{0} \\
\mathbf{0} & \boldsymbol{X}_{2}
\end{array}\right]_{2 n \times\left(m_{1}+m_{2}+2\right)} \quad \boldsymbol{\beta}^{*}=\left[\begin{array}{l}
\boldsymbol{\beta}_{1} \\
\boldsymbol{\beta}_{2}
\end{array}\right]_{\left.\left(m_{1}+m_{2}+2\right) \times 1\right)} \quad \boldsymbol{\varepsilon}^{*}=\left[\begin{array}{c}
\boldsymbol{\varepsilon}_{1} \\
\boldsymbol{\varepsilon}_{2}
\end{array}\right]_{(2 n \times 2 n)} \quad \boldsymbol{Y}_{k}=\left[\begin{array}{c}
y_{1} \\
y_{2} \\
\vdots \\
y_{n}
\end{array}\right]_{n \times 1} \\
& \boldsymbol{X}_{k}=\left[\begin{array}{ccccc}
1 & \left(x_{1}-x_{o}{ }^{(k)}\right) & \left(x_{1}-x_{o}{ }^{(k)}\right)^{2} & \cdots & \left(x_{1}-x_{o}{ }^{(k)}\right)^{m_{k}} \\
1 & \left(x_{2}-x_{o}{ }^{(k)}\right) & \left(x_{2}-x_{o}{ }^{(k)}\right)^{2} & \cdots & \left(x_{2}-x_{o}{ }^{(k)}\right)^{m_{k}} \\
\vdots & \vdots & \vdots & \ddots & \vdots \\
1 & \left(x_{n}-x_{o}{ }^{(k)}\right) & \left(x_{n}-x_{o}{ }^{(k)}\right)^{2} & \cdots & \left(x_{n}-x_{o}{ }^{(k)}\right)^{m_{k}}
\end{array}\right]_{n \times\left(m_{k}+1\right)} \quad \boldsymbol{\beta}_{k}=\left[\begin{array}{c}
\beta_{0_{k}} \\
\beta_{1_{k}} \\
\beta_{2_{k}} \\
\vdots \\
\beta_{m_{k}}
\end{array}\right]_{\left(m_{k}+1\right) \times 1} \quad \boldsymbol{\varepsilon}_{k}=\left[\begin{array}{c}
\varepsilon_{k 1} \\
\varepsilon_{k 2} \\
\varepsilon_{k 3} \\
\vdots \\
\varepsilon_{k n}
\end{array}\right]_{n \times 1}
\end{aligned}
$$

Menurut ${ }^{[13]}$ cara untuk menggabungkan bobot $\boldsymbol{K}$ dalam polinomial lokal dengan $\boldsymbol{V}$ pada regresi birespon adalah:

$$
\boldsymbol{L}=\left(\boldsymbol{Y}^{*}-\boldsymbol{X}^{*} \boldsymbol{\beta}^{*}\right)^{\prime} \boldsymbol{K}^{*} \boldsymbol{V}^{-1}\left(\boldsymbol{Y}^{*}-\boldsymbol{X}^{*} \boldsymbol{\beta}^{*}\right)
$$

dengan $\boldsymbol{K}^{*}=\left[\begin{array}{cc}\boldsymbol{K}_{1} & \mathbf{0} \\ \mathbf{0} & \boldsymbol{K}_{2}\end{array}\right] \boldsymbol{K}_{k}=\operatorname{diag}\left\{K_{h_{k}}\left(x_{i}-x_{0}{ }^{(k)}\right)\right\} ; i=1,2, \ldots, n ; k=1,2$. Estimator $\boldsymbol{\beta}^{*}$ diperoleh dengan meminimumkan $\boldsymbol{L}$ sehingga diperoleh:

$$
\widehat{\boldsymbol{\beta}}^{*}=\left[\boldsymbol{X}^{*^{\prime}} \boldsymbol{K}^{*} \boldsymbol{V}^{-1} \boldsymbol{X}^{*}\right]^{-1} \boldsymbol{X}^{*^{\prime}} \boldsymbol{K}^{*} \boldsymbol{V}^{-1} \boldsymbol{Y}^{*}
$$

Berdasarkan Persamaan 14 diperoleh estimator model regresi nonparametrik birespon polinomial lokal sebagai berikut:

$$
\widehat{\boldsymbol{Y}}^{*}=\boldsymbol{X}^{*} \widehat{\boldsymbol{\beta}}^{*}=\boldsymbol{X}^{*}\left[\boldsymbol{X}^{*^{\prime}} \boldsymbol{K}^{*} \boldsymbol{V}^{-1} \boldsymbol{X}^{*}\right]^{-1} \boldsymbol{X}^{*^{\prime}} \boldsymbol{K}^{*} \boldsymbol{V}^{-1} \boldsymbol{Y}^{*}=\boldsymbol{H} \boldsymbol{Y}^{*}
$$

dengan $\boldsymbol{H}=\boldsymbol{X}^{*}\left[\boldsymbol{X}^{*^{\prime}} \boldsymbol{K}^{*} \boldsymbol{V}^{-1} \boldsymbol{X}^{*}\right]^{-1} \boldsymbol{X}^{*^{\prime}} \boldsymbol{K}^{*} \boldsymbol{V}^{-1}$

\subsection{Uji Korelasi}

Uji korelasi diperlukan untuk mengetahui apakah terdapat korelasi di antara kedua variabel respon. Pengujian dilakukan dengan hipotesis:

$\mathrm{H}_{0}: \rho_{1,2}=0$ (Tidak ada korelasi antara $Y_{1}$ dan $\left.Y_{2}\right)$

$\mathrm{H}_{1}: \rho_{1,2} \neq 0$ (Ada korelasi antara $Y_{1}$ dan $Y_{2}$ ).

Statistik uji yang digunakan adalah:

$$
t=\frac{r_{1,2} \sqrt{n-2}}{\sqrt{1-r_{1,2}^{2}}}
$$

dengan $r_{1,2}=\frac{\sum_{i=1}^{n}\left(Y_{1 i}-\bar{Y}_{1}\right)\left(Y_{2 i}-\bar{Y}_{2}\right)}{\left\{\sum_{i=1}^{n}\left(Y_{1 i}-\bar{Y}_{1}\right)^{2}\right\}^{\frac{1}{2}}\left\{\sum_{i=1}^{n}\left(Y_{2 i}-\bar{Y}_{2}\right)^{2}\right\}^{\frac{1}{2}}}$

$t$ berdistribusi student $-t$ dengan derajat bebas $n-2$. Dengan taraf signifikansi $\alpha$ yang ditentukan, daerah penolakan $\mathrm{H}_{0}$ adalah $|t| \geq t_{1-\frac{\alpha}{2} ; d f=n-2}$.

\subsection{General Cross Validation (GCV)}

Bandwidth merupakan ukuran seberapa lebar persekitaran di titik lokal dan jika badwidth yang dipilih terlalu kecil bias model menjadi kecil akan tetapi karena banyak data yang berada pada persekitaran juga kecil menyebabkan varian menjadi besar, sedangkan jika bandwidth terlalu besar model bias akan menjadi besar ${ }^{[3]}$. Metode yang digunakan dalam pemilihan 
bandwidth optimal adalah dengan meminimumkan nilai General Cross Validation (GCV), sebagai berikut ${ }^{[12]}$ :

$$
G C V=\frac{\frac{1}{N}||(I-H) Y^{*}||^{2}}{\left[\frac{1}{N} T r(I-H)\right]^{2}}
$$

\subsection{R Square dan MAPE}

$R$ Square menunjukkan proporsi dari total varian pada variabel respon yang dapat dijelaskan oleh model regresi. Nilai $R$ Square untuk pemodelan birespon $R_{b}^{2}$ dinyatakan sebagaimana pada Persamaan 24 berikut $^{[8]}$ :

$$
R_{b}^{2}=\frac{\sum_{k=1}^{2} \sum_{i=1}^{n}\left(\hat{Y}_{k i}-\bar{Y}_{k}\right)^{2}}{\sum_{k=1}^{2} \sum_{i=1}^{n}\left(Y_{k i}-\bar{Y}_{k}\right)^{2}}
$$

MAPE digunakan untuk mengetahui akurasi prediksi dari suatu model. Kriteria akurasi model berdasarkan nilai MAPE adalah MAPE < 10\% berarti akurasi model tinggi, 10\% $\leq$ MAPE < $20 \%$ berarti akurasi model baik, 20\% $\leq$ MAPE $<50 \%$ berarti akurasi model cukup baik, dan MAPE $>50 \%$ berarti model tidak akurat ${ }^{[1]}$. Nilai MAPE didefinisikan sebagaimana Persamaan 19 berikut:

$$
M A P E=\frac{1}{N} \sum_{k=1}^{2} \sum_{i=1}^{n}\left(\frac{\left|e_{k i}\right|}{\left|Y_{k i}\right|}\right) 100 \%
$$

dengan $N=2 n$ dan $e_{k i}=Y_{k i}-\hat{Y}_{k i}, k=1,2$.

\subsection{Indeks Harga Saham Gabungan dan Kurs USD}

Salah satu indikator yang digunakan untuk mengetahui pergerakan harga saham adalah indeks harga saham. IHSG merupakan salah satu indeks harga saham yang meliputi pergerakan harga saham biasa dan saham preferen dengan menggunakan seluruh perusahaan tercatat dalam perhitungan indeks ${ }^{[10]}$. Sedangkan nilai tukar atau kurs adalah harga satu unit mata uang asing dalam mata uang domestik atau juga sebaliknya.

${ }^{[9]}$ Berdasarkan pendekatan keseimbangan portofolio, terjadinya depresiasi rupiah terhadap mata uang asing dapat menurunkan biaya impor bagi penduduk asing dengan kata lain akan meningkatkan angka permintaan barang dalam negeri. Tingginya permintaan ekspor ini akan meningkatkan arus dana masuk bagi perusahaan domestik sehingga dapat meningkatkan kinerjanya karena ketersediaan dana yang cukup. Hal ini akan menyebabkan terjadinya kenaikan IHSG.

\subsection{Suku Bunga Bank Indonesia}

$B I$ rate merupakan suku bunga acuan yang ditetapkan BI setiap bulan berdasarkan rapat para dewan gubernur dengan mempertimbangkan kondisi perekonomian baik nasional maupun global. Salah satu faktor pertimbangan penetapan BI rate adalah inflasi. Apabila inflasi tinggi maka $B I$ rate juga akan tinggi dengan tujuan agar perbankan umum juga meningkatkan suku bunga deposito sehingga dapat mengurangi jumlah uang yang beredar di masyarakat. 
Suku bunga BI memiliki pengaruh terhadap IHSG karena investor dalam memilih instrumen investasi tidak hanya mempertimbangkan nilai return tetapi juga melihat tingkat suku bunga yang diperoleh apabila diinvestasikan di bank ${ }^{[10]}$. Berdasarkan hal tersebut, maka apabila suku bunga deposito perbankan tinggi maka investor akan cenderung berinvestasi pada deposito daripada saham. Penelitian dilakukan oleh ${ }^{[5]}$, yang menunjukkan bahwa suku bunga juga berpengaruh secara signifikan negatif terhadap IHSG. Sedangkan perubahan dalam suku bunga domestik seringkali menjadi faktor yang mempengaruhi nilai tukar. Hal ini dikarenakan perubahan suku bunga relatif mempengaruhi investasi sekuritas-sekuritas asing, yang selanjutnya akan mempengaruhi permintaan dan penawaran sekuritas asing. Penelitian dilakukan oleh ${ }^{[6]}$ yang memodelkan pengaruh suku bunga terhadap nilai tukar menunjukkan bahwa suku bunga berpengaruh signifikan terhadap nilai tukar.

\subsection{Program $R$ dan Graphycal User Interface}

$R$ adalah sebuah bahasa pemograman dan lingkungan/environment untuk komputasi statistik dan grafik yang berbasis command line sehingga dikembangkanlah GUI $R$ dengan tujuan untuk mempermudah pengguna. Terdapat beberapa packages dalam $R$ yang dapat digunakan untuk membuat GUI salah satunya adalah dengan Shinny Packages yang memiliki komponen user interface dan server. Selain itu terdapat Shinny dashboard yaitu package dalam $R$ yang berfungsi untuk meningkatkan user interface program.

\section{METODOLOGI PENELITIAN}

\subsection{Sumber Data dan Variabel Penelitian}

Data yang digunakan dalam penelitian ini diperoleh dari website Bank Indonesia (https://www.bi.go.id) dan investing.com. Data tersebut adalah data harga penutupan IHSG dan nilai tukar USD, serta data 7 day repo rate dengan periode bulanan mulai dari Bulan Agustus 2016 hingga Desember 2019. Dalam penelitian ini indeks harga saham gabungan $\left(Y_{1}\right)$ dan nilai tukar USD $\left(Y_{2}\right)$ sebagai variabel respon sedangkan 7 Day Repo Rate $(X)$ sebagai variabel prediktor.

\subsection{Langkah-langkah Analisis}

Langkah pertama dalam penelitian ini adalah melakukan penyusunan program GUI $R$ selanjutnya dilakukan pemodelan menggunakan program yang telah disusun, dengan langkah: sebagai berikut:

a. Melakukan impor data dengan format $c s v$.

b. Melakukan uji korelasi antar respon untuk mengetahui ada tidaknya hubungan antar respon.

c. Melakukan pembagian data menjadi data training dan data testing dengan proporsi 3:1. 
d. Melakukan eksplorasi data meliputi analisis statistika deskriptif pada variabel respon dan prediktor serta analisis secara grafis dengan menggunakan scatter plot antara prediktor dengan respon.

e. Menentukan matriks pembobot $\boldsymbol{V}^{-1}$ untuk data training.

f. Menentukan fungsi kernel, order setiap respon, titik lokal, batas bawah, batas atas, dan pertambahan bandwidth untuk setiap respon yang akan digunakan.

g. Melakukan estimasi model berdasarkan data training.

h. Menghitung nilai General Cross Validation dari masing-masing model.

i. Menentukan kombinasi bandwidth, titik lokal, order dan fungsi kernel optimal berdasarkan nilai GCV minimum.

j. Melakukan estimasi model optimal yang diperoleh.

k. Menghitung nilai $R$-Square berdasarkan data training.

1. Melakukan prediksi data testing dan melakukan pengukuran akurasi model berdasarkan nilai MAPE.

\section{ANALISIS DAN PEMBAHASAN}

\subsection{Penyusunan Graphical User Interface R-Studio}

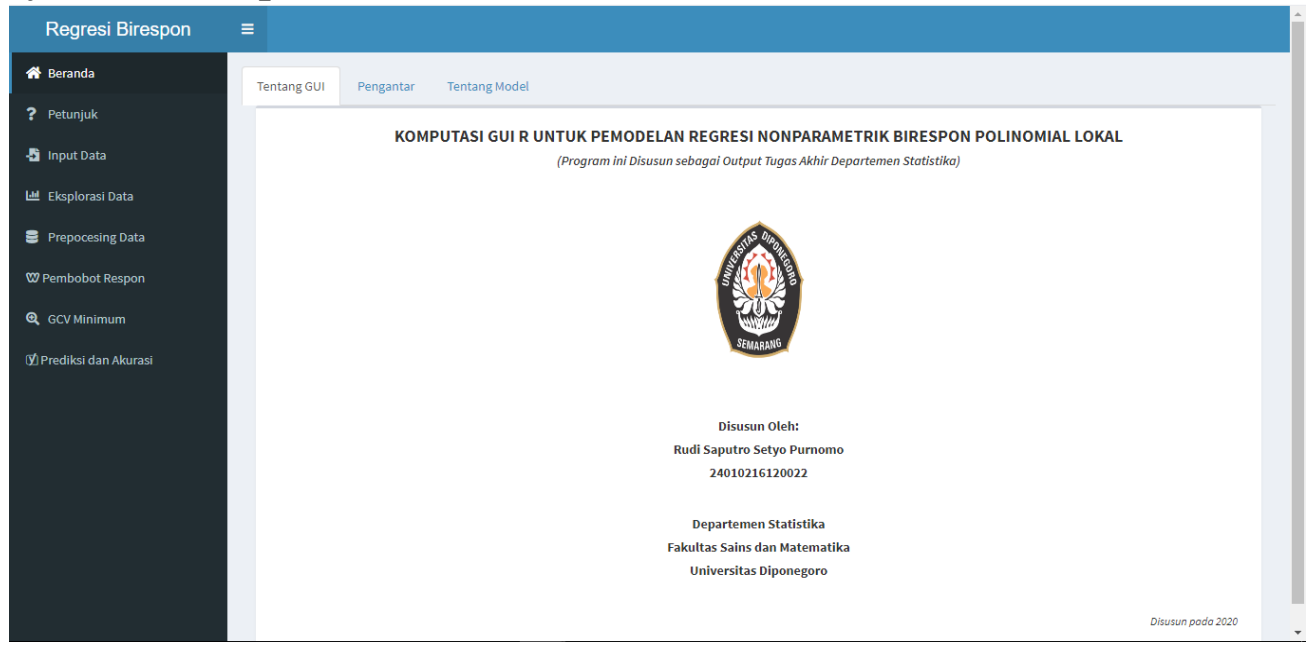

Gambar 1. Tampilan Menu "Beranda"

Dalam penelitian ini dilakukan penyusunan program komputasi berbasis GUI. Langkah awal yang dilakukan adalah penyusunan tampilan antar muka selanjutnya penyusunan server. Terdapat tiga bagian utama dari GUI yang disusun yaitu halaman depan dan pemodelan yang tersaji pada Gambar 1 dan Gambar 2. 


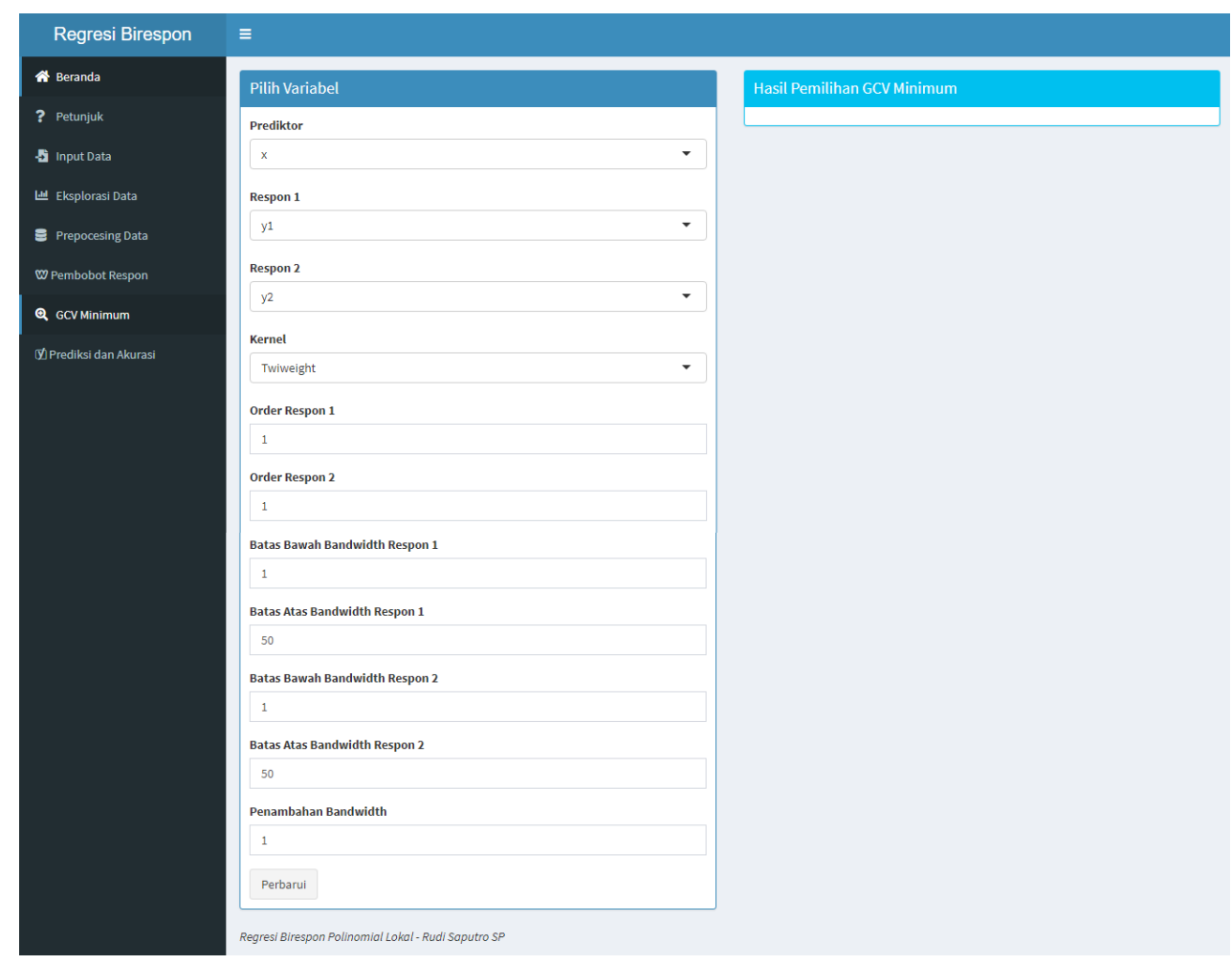

Gambar 2. Tampilan Menu "GCV Minimum”

\subsection{Uji Korelasi Respon}

Dilakukan pengujian korelasi untuk mengetahui ada tidaknya korelasi antara IHSG dan Kurs USD, yaitu dengan pengujian hipotesis berikut:

Hipotesis:

$\mathrm{H}_{0}: \rho_{1,2}=0$ (Tidak ada korelasi antara IHSG dan Kurs USD)

$\mathrm{H}_{1}: \rho_{1,2} \neq 0$ (Ada korelasi antara IHSG dan Kurs USD)

Jika diambil $\alpha=5 \%$, maka $\frac{\alpha}{2}=0,025$ dan derajat bebasnya adalah $n-2=41-2=39$, sehingga diperoleh nilai kritis yaitu $t_{0,975 ; d f=39}=2,0227$. Nilai statistik uji yang diperoleh adalah $t=3,2141$ dengan $p$ value $=0,0026$. Daerah penolakan $H_{0}$ adalah $|t| \geq 2,0227$, karena 3,2141 berada di daerah penolakan $\mathrm{H}_{0}$ maka $\mathrm{H}_{0}$ ditolak. Sehingga dengan taraf signifikansi $\alpha=5 \%$ dapat disimpulkan bahwa terdapat korelasi antara IHSG dan Kurs USD.

\subsection{Eksplorasi Data}

Data training yang digunakan dalam penelitian adalah data mulai bulan Agustus 2016 hingga Februari 2019. Sedangkan data testing yang digunakan untuk mengukur akurasi prediksi dari model adalah data mulai dari Maret 2019 hingga Desember 2019. Berdasarkan Tabel 1 diketahui bahwa pada periode Agustus 2016 hingga Februari 2019 nilai IHSG berada di sekitar rata-ratanya yaitu 5.877,414, sedangkan nilai Kurs USD berada di sekitar 13.748,050. Berdasarkan hasil perhitungan diperoleh nilai minimum dan maksimum dari Kurs USD adalah 
$4,25 \%$ dan $6,00 \%$. Sehingga titik kelokalan yang dicobakan dalam penelitian adalah titik-titik dalam rentang $4,25 \%$ sampai dengan $6,00 \%$.

Tabel 1. Statistik Deskriptif Variabel IHSG dan Kurs USD

\begin{tabular}{lrc}
\hline Variabel & Rata-rata & Varian \\
\hline IHSG & $5.877,414$ & $155.386,700$ \\
Kurs USD & $13.748,050$ & $304.391,500$ \\
\hline
\end{tabular}

Gambar 3 menunjukkan bahwa antara suku bunga BI dengan IHSG maupun Kurs USD samasama sedikit memiliki pola. Pemodelan regresi nonparametrik dapat digunakan untuk memodelkan data dengan bentuk apa saja. Sehingga pemodelan ini sesuai untuk digunakan.

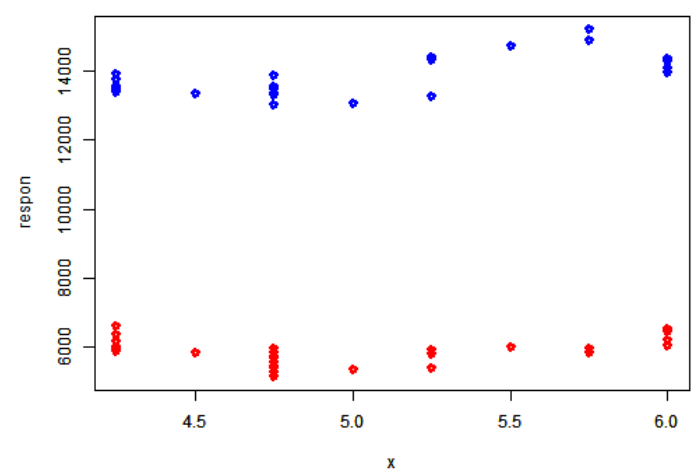

Gambar 3. Grafik Scatter Plot Suku Bunga BI dan IHSG (warna merah) dan Suku Bunga BI dan Kurs USD (warna biru).

\subsection{Pemodelan Regresi Birespon Polinomial Lokal pada IHSG dan Kurs USD}

Dalam pemodelan regresi birespon perlu disusun matriks pembobot $\boldsymbol{V}^{-1}$. Berdasarkan output diperoleh matriks varian kovarian respon sebagai berikut:

$$
\boldsymbol{\Sigma}=\left[\begin{array}{cc}
155.386,74 & 80.275,04 \\
80.275,04 & 304.391,46
\end{array}\right]
$$

Berdasarkan matriks tersebut maka dapat disusun matriks $\boldsymbol{V}$ yaitu matriks blok berukuran $62 \times$ 62 sebagaimana dalam Persamaan 10, yaitu:

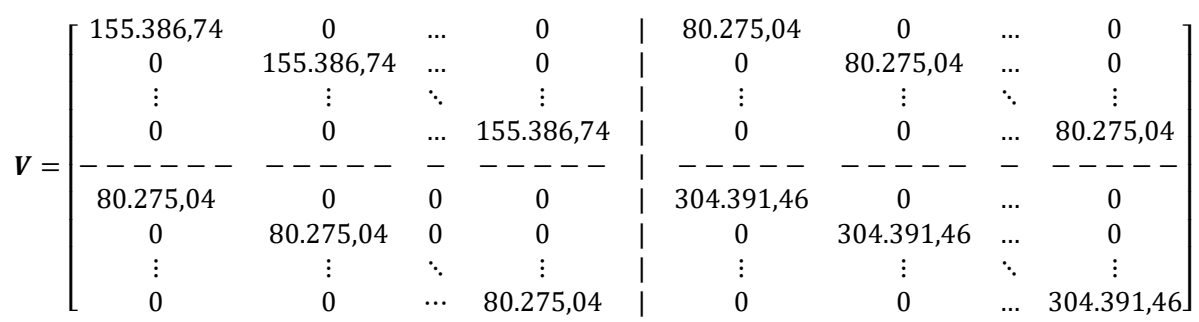

Pemodelan regresi nonparametrik birespon polinomial lokal selanjutnya diterapkan pada data training indeks harga saham gabungan dan kurs USD berdasarkan suku bunga BI. Fungsi kernel yang digunakan adalah fungsi kernel segitiga, fungsi kernel triweight, dan fungsi kernel gaussian. Dalam setiap pemodelan fungsi kernel yang digunakan adalah sama untuk kedua 
respon. Nilai bandwidth yang digunakan berada pada rentang 1 hingga 50 dengan penambahan sebesar 1 dan juga pada rentang 0,1 hingga 1,9 dengan penambahan 0,1. Apabila GCV mencapai nilai minimum pada nilai bandwith tertinggi maka akan dilakukan penambahan rentang bandwidth, begitu pula sebaliknya jika nilai GCV minimum dicapai pada nilai bandwidth terkecil. Selain itu apabila nilai GCV minimum tercapai pada titik di antara 1 dan 50 maka akan dicari bandwidth yang lebih optimal dengan mengubah penambahan bandwidth menjadi 0,1. Titik kelokalan yang dicobakan adalah sebagaimana dijelaskan pada sub bab 4.2. Sedangkan pangkat tertinggi model yang dicobakan adalah pangkat satu hingga tiga. Dalam penelitian ini nilai bandwidth, titik kelokalan, dan pangkat tertinggi model antara respon satu dan dua dapat berbeda yaitu merupakan kombinasi. Setelah dilakukan percobaan diperoleh hasil bahwa untuk semua fungsi kernel yang digunakan nilai GCV minimum jatuh pada model dengan kombinasi order dua dan tiga. Hasil tersebut tersaji pada Tabel 2.

Tabel 2. Model Optimal Setiap Fungsi Kernel

\begin{tabular}{lrrrrr}
\hline \multirow{2}{*}{ Fungsi Kernel } & \multicolumn{2}{c}{ Bandwidth } & \multicolumn{2}{c}{ Titik Kelokalan } & \multirow{2}{*}{ GCV } \\
& Respon 1 & Respon 2 & Respon 1 & Respon 2 & \\
\hline Segitiga & 6,00 & 2,70 & 5,75 & 6,00 & $91.478,18$ \\
Triweight & 4,70 & 3,20 & 6,00 & 6,00 & $91.572,51$ \\
Gaussian & 1,90 & 1,20 & 6,00 & 6,00 & $91.545,19$ \\
\hline
\end{tabular}

Berdasarkan nilai GCV dalam Tabel 2 diketahui juga bahwa perbedaan nilai GCV antar fungsi kernel tidak jauh berbeda. Namun nilai GCV yang paling minimum adalah model dengan menggunakan fungsi kernel segitiga. Selanjutnya dilakukan estimasi model optimal dan diperoleh estimator model untuk IHSG dan kurs USD sebagai berikut:

$$
\left[\begin{array}{l}
\hat{y}_{1 i} \\
\hat{y}_{2 i}
\end{array}\right]=\left[\begin{array}{c}
5.960,6410+1.283,194\left(x_{i}-5,75\right)+946,6518\left(x_{i}-5,75\right)^{2} \\
14.285,05-2.782,595\left(x_{i}-6\right)-5.467,923\left(x_{i}-6\right)^{2}-2.097,577\left(x_{i}-6\right)^{3}
\end{array}\right]
$$

Jika dilakukan prediksi menggunakan model tersebut terhadap data training akan diperoleh plot prediksi yang tersaji dalam Gambar 4.

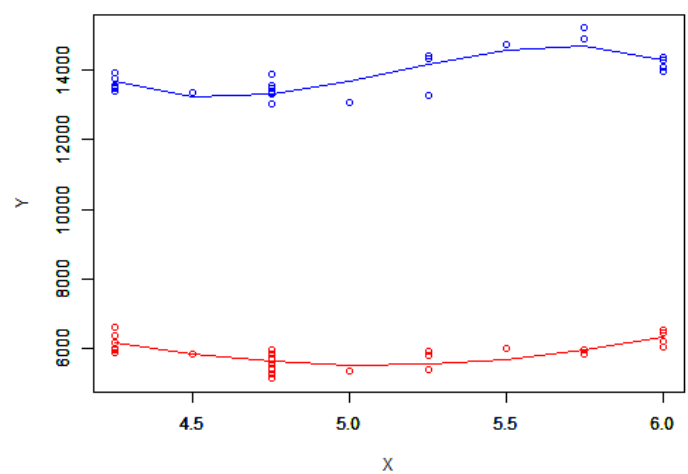

Gambar 4. Plot Prediksi Model dengan Fungsi Kernel Segitiga Kombinasi Order Dua dan Tiga. 
Gambar 4 menunjukkan bahwa kurva /garis (plot prediksi) dapat mendekati titik-titik data aktual bahkan beberapa titik dapat terpotong oleh kurva prediksi. Prediksi IHSG ditunjukkan oleh kurva berwarna merah sedangkan kurs USD berwarna biru.

Berdasarkan hasil prediksi data training dilakukan perhitungan $R$ Square dengan Persamaan 18. Nilai $R$ Square yang diperoleh adalah sebesar 0,6668 yang menunjukkan bahwa suku bunga BI mempengaruhi sebesar 66,68\% varian pada respon IHSG dan kurs USD dan sisanya sebesar $33,32 \%$ dipengaruhi oleh faktor lain. Untuk mengetahui tingkat akurasi model dalam melakukan prediksi terhadap data di luar pemodelan maka dilakukan prediksi terhadap data testing dengan hasil tersaji pada Tabel 3.

Tabel 3. Hasil Prediksi dan Nilai Aktual Data Testing berdasarkan Model Optimal

\begin{tabular}{llcc}
\hline \multicolumn{2}{c}{ IHSG } & \multicolumn{2}{c}{ Kurs USD } \\
\hline Aktual & Prediksi & Aktual & Prediksi \\
\hline $6.228,320$ & $5.530,737$ & $14.037,000$ & $13.697,300$ \\
$6.128,350$ & $5.530,737$ & $14.073,000$ & $13.697,300$ \\
$6.299,540$ & $5.530,737$ & $13.882,500$ & $13.697,300$ \\
$6.169,100$ & $5.555,707$ & $14.195,000$ & $14.181,210$ \\
$6.328,470$ & $5.699,008$ & $14.185,000$ & $14.571,560$ \\
$6.390,510$ & $5.960,641$ & $14.017,000$ & $14.671,730$ \\
$6.468,760$ & $6.340,605$ & $14.240,000$ & $14.285,050$ \\
$6.455,350$ & $6.340,605$ & $14.250,000$ & $14.285,050$ \\
$6.209,120$ & $6.340,605$ & $14.275,000$ & $14.285,050$ \\
$6.358,630$ & $6.340,605$ & $14.127,500$ & $14.285,050$
\end{tabular}

Berdasarkan hasil prediksi pada Tabel 3 tersebut, dapat disusun plot hasil prediksi dan data aktual IHSG serta kurs USD pada Gambar 5. Berdasarkan gambar tersebut diketahui bahwa kurva hasil prediksi (garis) dapat mendekati beberapa titik-titik data aktual meskipun tidak semuanya baik pada IHSG (warna merah) maupun Kurs USD (warna biru).

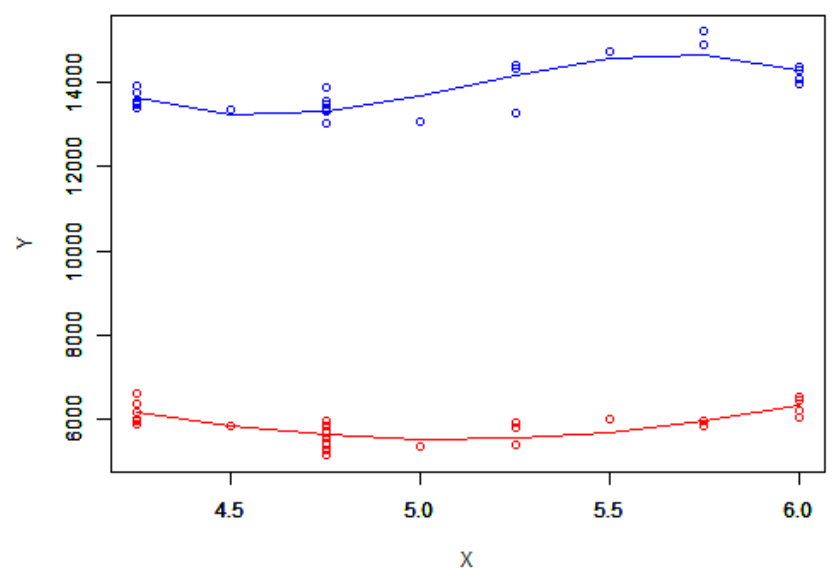

Gambar 5. Plot Prediksi Data Testing Berdasarkan Model Optimal. 


\section{KESIMPULAN}

Kesimpulan yang diperoleh dari hasil analisis dan pembahasan pada penelitian ini adalah:

1. Dengan aplikasi berbasis Graphycal User Interface (GUI) dapat mempermudah pengguna untuk melakukan komputasi pemodelan regresi nonparametrik birespon dengan pendekatan polinomial lokal sesuai dengan algoritma pemodelan yang ditetapkan.

2. Pemodelan regresi tersebut diterapkan pada indeks harga saham gabungan dan kurs USD sebagai variabel respon pertama $\left(Y_{1}\right)$ dan variabel respon kedua $\left(Y_{2}\right)$, serta suku bunga BI sebagai variabel prediktor $(X)$ dengan aplikasi GUI $R$-Studio.

3. Berdasarkan kriteria GCV minimum diperoleh model optimal dengan fungsi kernel segitiga serta kombinasi bandwidth $h_{1}=6$ dan $h_{2}=2,7$. Model optimal tersebut adalah:

$$
\begin{aligned}
& \hat{y}_{1 i}=5.960,6410+1.283,194\left(x_{i}-5,75\right)+946,6518\left(x_{i}-5,75\right)^{2} \\
& \hat{y}_{2 i}=14.285,05-2.782,595\left(x_{i}-6\right)-5.467,923\left(x_{i}-6\right)^{2}-2.097,577\left(x_{i}-6\right)^{3} .
\end{aligned}
$$

4. Nilai $R$ Square dari model optimal yang diperoleh adalah sebesar 0,6668 yang menunjukkan bahwa suku bunga BI mempengaruhi sebesar 66,68\% variasi pada respon IHSG dan kurs USD dan sisanya sebesar 33,32\% dipengaruhi oleh faktor lain. Selain itu model tersebut memiliki tingkat akurasi prediksi yang tinggi dengan nilai MAPE sebesar 4,0798\%.

\section{DAFTAR PUSTAKA}

[1] Chen, R. J. C., Bloomfield, P., dan Cubbage, F. W. 2008. Comparing Forecasting Models in Tourism. Journal of Hospitality \& Tourism Research Vol. 32, No. 1: 3-21.

[2] Eubank, R. L. 1999. Nonparametric Regression and Spline Smoothing. Edisi 2. New York: Marcel Dekker, Inc.

[3] Fan, J. dan Gijbels, I. 1996. Local Polynomial Modelling and Its Applications. London: Chapman \& Hall.

[4] Hardle, W. dan Linton, O. (McFadden, D. F. dan Engle, R. F.). 1994. Applied Nonparametric Methods. Handbook of Econometrics Vol. 4: Hal. 2295-2339.

[5] Harsono, A. R. dan Worokinasih, S. 2018. Pengaruh Inflasi, Suku Bunga, dan Nilai Tukar Rupiah terhadap Indeks Harga Saham Gabungan (Studi pada Bursa Efek Indonesia Periode 2013-2017). Jurnal Administrasi Bisnis (JAB) Vol. 60, No. 2: Hal. 102-110.

[6] Kirana, M. P. A. 2017. Pengaruh Tingkat Bunga SBI terhadap Nilai Tukar Rupiah Studi pada Bank Indonesia. Equilibrium Vol. 5, No. 1: Hal. 70-80. 
[7] Nurrohim, M. 2013. Analisis Kausalitas Volatilitas Nilai Tukar Mata Uang dengan Kinerja Sektor Keuangan dan Sektor Riil. Economics Development Analysis Journal Vol. 2, No. 4: Hal. 351-366.

[8] Rahmawati, R. D., Suparti, dan Prahutama, A. 2019. Pemodelan Inflasi dan Indeks Harga Saham Gabungan Menggunakan Regresi Nonparametrik Birespon Spline Truncated dengan Pembobot Invers Matriks Variansi Kovariansi Error Respon. Statistika Vol. 7, No. 1: Hal. 29-38.

[9] Sudirman (Darwis, R). 2015. Pasar Modal dan Manajemen Portofolio. Gorontalo: Sultan Amai Press IAIN Sultan Amai.

[10] Sunariyah. 2004. Pengetahuan Pasar Modal. Edisi 5. Yogyakarta: Unit Penerbit dan Percecatak (UMP) AMP YKPN.

[11] Suparti dan Prahutama, A. 2016. Pemodelan Regresi Nonparametrik Menggunakan Pendekatan Polinomial Lokal pada Beban Listrik di Kota Semarang. Media Statistika Vol. Vol. 9, No. 2: Hal. 85-93

[12] Wahba, G. 1990. Spline Models for Observational Data. Philadelphia: Society for Industrial and Applied Mathematics.

[13] Welsh, A. H. dan Yee, T. W. 2005. Local Regression for Vector Responses. Journal Statistical planning and inference Vol. 136, No. 2006: Hal. 3007-3031.

[14] Wu, H. dan Zhang, J. T. 2006. Nonparametric Regression Methods for Longitudinal Data Analysis. Canada: A John Wiley \& Sons, Inc. Publication. 